تأثير المعالجة بالبلازما على قابلية أقمشة الميكرو فيبر للتفصيل

\title{
The effect of plasma treatment on the
} ability of microfiber fabrics to be tailored أ.م. د/ وجدي صلاح الدين أحمد السيسي - استاذ تصميم الملابس والحلى - الحئ

المشارك - كلية علوم الأسرة - جامعة طيبة - المملكة العربية السعودية

أ.د/ عادل محمد الحديدي - استاذ هنسة الدنسوجات المتفرغ بكلية الهندة -

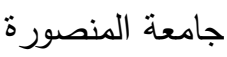

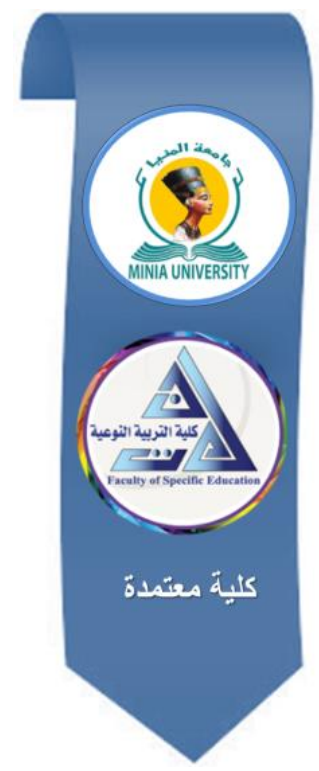

\section{مجلة البحوث في مجالاث التربية التوعية}

معرف البحث الرقمي DOI: 10.21608/jedu.2021.83763.1403

المجلد الثُامن العدد 40 ـ مايو 2022

$$
\text { الترقيم الدولي }
$$

\section{E- ISSN: 2735-3346 P-ISSN: 1687-3424}

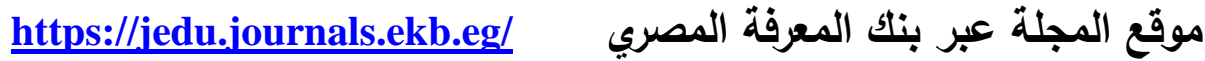

http://jrfse.minia.edu.eg/Hom موقع المجلة موتع المبه العنوان: كلية التربية النوعية ـ جامعة المنيا ـ جمهورية مصر العربية

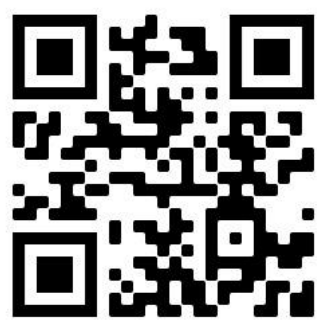


مجلة البحوث فى مجالات التربية النوعية 
تأثير المعالجة بالبلازما على قابلية أقمشة الميكرو فيبر للتفصيل

أ.م. د/ وجدي صلاح الدين أحمد السيسي - استاذ تصميم الملابس والحلى المشارك - كلية علوم

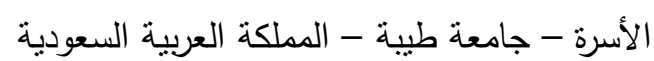

أ.د/ عادل محمد الحديدي - استاذ هندسة المنسوجات المتقرغ بكلية الهندسة - جامعة المنصورة

الملخص

تتميز أقمشة الألياف الدقيقة من البولي استر بالعديد من الخصائص الجمالية، منل النعومة الفائقة

ولا يقلل ذلك من استخداماتها في صناعه الملابس الا ان نعومتها الفائقة (أقل من واحد دنير) تسبب العديد من المشاكل اثناء تصنيع الملابس خصوصا بعد قص الباتر ونات واحتمالات انزلاق المقصوصات.

من جهة اخرى تسبب المعالجات الرطبة للأقمشة في العديد من المشاكل القومية المصرية، منل الاستهلاك العالي للمياه واستخدام كيماويات عديدة والتي تحدث تلوثا كبيرا، بالإضافة الى الاستهلاك العالي للكهرباء.

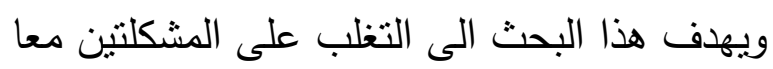
بما أن المعالجة الجافة للمنسوجات (المعالجة بالبلازما) لها أربع وظائف، منها النحر فإن معالجة سطح الأقمشة بغاز غير مبلمر يؤدي إلى خشونة سطح القماش مما يمنع بالِ الأقششة من الانزلاق بعد فصل اجزاء الباترون.

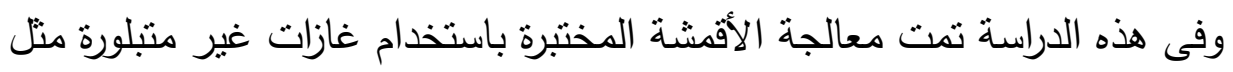
الهيليوم والارجون والنيتروجين بالإضافة الى الهواء في تغير خواص السطح لأفمشة الميكرو فيبر عالية النعومة.

واثبت الدراسة تحسن دليل قابلية الأقمشة للتقصيل من 18\% (للقماش الخام) الى 30 بعد معالجة القماش المختبر بالنيتروجين والارجون على الترتيب.

وتوصى الدراسة الى صلاحية استخدام المعالجات الجافة كبديل للمعالجات الرطبة لئل وتحسبن قابلية الأقمشة للتفصيل، وكذا التغلب على بعض المشاكل القومية المصاحبة للمعالجات الرطبة. 


$$
\begin{aligned}
& \text { الكلمات المفتاحية: أقمشة الألياف فائقة النعومة من البولي استر - المعالجات الجافة } \\
& \text { (البلازما) - الغازات النبيلة (الارجون - النيتروجين - الهيليوم- الهواء) - دليل قابلية } \\
& \text { الاقششة للتفصيل - المشاكل القومية المصرية. }
\end{aligned}
$$

\section{The effect of plasma treatment on the ability of microfiber}

\section{fabrics to be tailored}

* EL-Sisy, W.S: Associate Professor of Apparel and jewelry Design Dept., Faculty of Family Science Taibah University, Saudi Arabia

* EL-Hadidy, A.M: professor Emeritus of textile Faculty of Engineering -

\section{Mansoura University}

\section{Abstract:}

The microfiber fabrics have many aesthetic properties, such as super smoothness. The aim of this research is to overcome the problems of detailing resulting from the smoothness of microfiber fabrics through dry treatment. This study aims to overcome the problems of individual ultra-fine fabrics.

Since the dry treatment of textiles (Plasma treatment), has four functions, treating the surface of the fabrics with an non- polymerized gas leads to a roughness of the surface of the fabric, which prevents the fabrics from slipping after spreading and and cutting.

The currently used high-performance micro-fiber fabrics for soft body armor have very low surface friction and this has become an issue in the effectiveness of ballistic energy absorption. In this study, nonpolymerizing reactive plasma gas $\mathrm{H} 2, \mathrm{Ar}, \mathrm{N} 2$ and air were employed to modify micro-fiber polyester fabric surface for the application of ballistic impact material. Capillary rise method observations yield information about the surface effect of the fabrics after plasma treatment. The surface morphology of the treated fabrics was studied. Fabric tailor ability analysis was used to analyze the surface properties of the treated samples. The yarn pulling-out test shows that the resistance to pulling out yarns from fabrics plasma-treated treated with $\mathrm{N} 2$ and Ar, plasma-treated fabric is increased $18 \%$ and $30 \%$ respectively, compared with the untreated fabric.

\section{Key words:}

Microfiber polyester fibers - Dry treatments (plasma) - Noble gases (argon - nitrogen - helium - air)- fabrics tailorability index - Egyptian national problems. 


\section{1- INTRODUCTION}

The garment industry is a three trillion-dollar industry that encompasses the manufacturing and sale of textile garments and has long been considered a source of economic progress around the world.

\section{Examples of smart technologies:}

1- Nano-membranes

2- E-Textiles

3- Seam-free garments

4 - Auxetic Fabrics

5- Phase Change Material

6 - Digital printing

7 - Wearable technology

8 - Heat regulation

9 - Impact protection

10 - Fire protection

11- Cost savings

12 - Smart Life Vest: “Our garment systems are based on knitted sensor structures which are multi-functional and integral to the garment's manufacture. These sensors are flexible and are registered as soft sensors contain discrete electrical, electronic, and knitted components, engineered to create polarized functionality or a body sensory network for monitoring physiological signs. We have created a variety of super comfortable easy to wear garments which read human vital signs directly from the skin. And can be worn in both strenuous and resting states. Our seamless Health Vest garment system works as demonstrated in the above 3D demo. Data collected by the Smart Life, Health Vest can be transmitted in real time via Bluetooth to a remote computer, PDA, or even a cell phone."

\subsection{What is "Microfiber" - Definition \& Explanation}

Microfiber is an extremely fine synthetic fiber used to produce extremely soft and lightweight fabrics. Microfiber is often defined as fibers of less than 1 denier per filament, but the term "microfiber" is loosely used in the industry. As it may be made with polyester, rayon, acrylic, nylon, or other fibers. It's used for rainwear, outerwear, and other various types of apparel. Microfibers are synthetic ultra-fine fibers available in acrylic, 
nylon, polyester, and rayon. When woven the produce is an extremely drape able, very soft and luxurious fabric.

This fabric is tightly woven from a very fine poly thread and has a seeded finish for a fancy, soft-smooth feel.

Microfiber fabric (in its natural state) is normally water repellent due to its manufacturing process and it can be specially treated to be completely waterproof. A fine synthetic fiber woven into washable, breathable, and lightweight fabrics that can shape extremely well.

\subsubsection{Polyester Microfiber Fabric is}

Those that feel cotton is king might not view other fabrics like polyester microfiber very favorably. As soon as many hear the word "polyester" they immediately think hot and non-breathable but today's polyester microfiber process is not the same as that of the 1950's. Technology has advanced to the point where microfiber fabric content actually provides benefits in appearance, care and durability.

\subsubsection{Here are Bid Benefits in Micro-fiber}

Comforter fabric shells, fill, sheets, and pillowcases made from microfiber have some surprising benefits and are worth a second look when deciding to buy bedding sets made with this material. Here are a few:

1. Microfiber is shrink resistant and a very strong material making it last longer

2. Fabric from woven microfibers are extremely soft, almost like silk, luxurious to the touch due to the tight weaving of thousands of ultra-fine fibers and unlike other fabrics that need to be washed several times to feel soft.

3. They resist wrinkles, mildew, stretching, shrinkage, abrasions and most stains

4. Microfibers resist static cling when compared to other fabrics

5. The colors stay true and vibrant longer

6. It offers insulating characteristics yet is still breathable

7. Perspiration and body oils pass through this fabric away from your body and provides a dry surface when touching your skin

8. It is less costly than cotton or cotton blends to produce with savings passed to the consumer. 


\subsubsection{What are microfiber cloths?}

Microfiber cleaning cloths are made out of microfiber fabrics made up of polyester and nylon together. Microfibers are much thinner in diameter than human hair within each fiber.

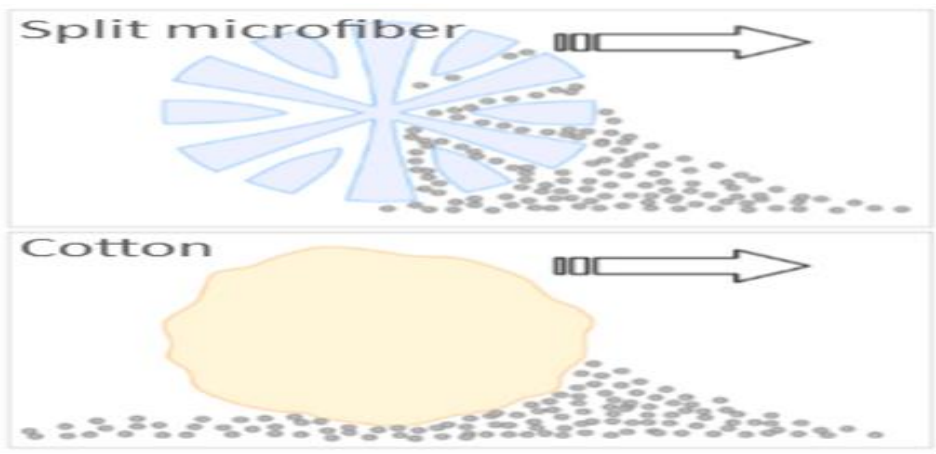

Fig (1) The concept of micro-fiber cleaning action.

Uses for microfiber cloths

Dusting surfaces. -

Cleaning mirrors and glass. -

Cleaning counters. Washing dishes. -

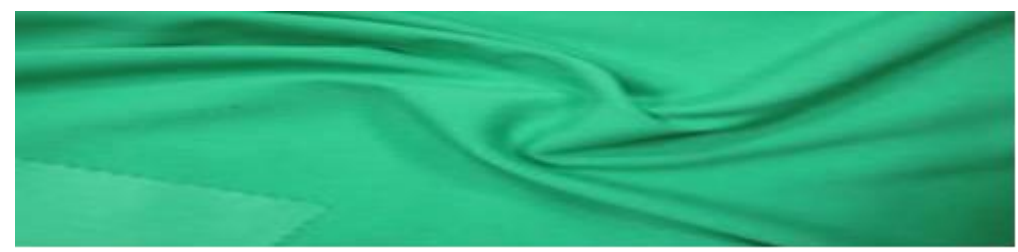

Fig(2) shows the micro-fiber polyester fabric.

\subsubsection{Cotton Pros and Cons :}

Cotton can be woven into fabric of varying weights suitable for upholstery. But cotton alone does not withstand abrasion as well as man-made fibers. Therefore, Synthetic fibers like polyester are often woven with cotton to boost the polyester's durability. This lowers the cotton's absorption qualities but boosts the durability considerably. Cotton can be easily dyed, is absorbent and is cool to the touch, that's why upholstered cotton pieces will absorb body moisture and give a cool feeling on hot days. Cotton's main weaknesses are that it easily wrinkles, can shrink when wet and is highly susceptible to sun-fade.

The high absorbability of cotton is weakend with the addition of polyester, despite that cotton fabric can still absorb certain fluids like 
ink, dye, food products and oil, most of which could still leave stains on the fabric. Due to the microfiber's thinness and its distinct strength when it's woven with nylon, microfiber upholstery fabric is very durable. It can be woven into a thin fabric that surpasses many thousands of rubs, which is the standard way of measurement for the durability of upholstery fabrics. But because it's a synthetic fiber and considering the fact that when it's made from polyester it is considered a product of the petroleum industry, and it cannot be considered organic or from renewable resources. These fibers are also resistant to sun-fade, the damage from UV rays.

\section{Aim of the work}

The textile industry is searching for innovative production techniques to improve the product quality, as well as society requires new finishing techniques working in environmental respect.

Plasma polymerization offers an attractive possibility to deposit functional thin films on textiles [1]. By using appropriate combinations of gas mixtures and plasma parameters, a rather broad range of surface properties can be imparted to fabrics. In comparison to plasma activation (where no film is deposited), the surface properties resulting from plasma polymerization are relatively independent of the chemical nature of the textile substrate (although the latter has to be taken into account for the adhesion of the film [2,3] The thickness of these films can be well controlled and kept within a range $(\sim 100 \mathrm{~nm})$ where the bulk properties of the textiles are not significantly altered.

This study aims to overcome the problems of individual ultra-fine fabrics.

Since the dry treatment of textiles (Plasma treatment), has four functions, treating the surface of the fabrics with an nonpolymerized gas leads to a roughness of the surface of the fabric, which prevents the fabrics from slipping after cutting.

The currently used high-performance micro-fiber fabrics for soft body armor have very low surface friction and this has become an issue in the effectiveness of ballistic energy absorption. In this study, non-polymerizing reactive plasma gas H2, N2, Ar and air were employed to modify micro-fiber polyester fabric surface for the application of ballistic impact material. Capillary rise method 
observations yield information about the surface effect of the fabrics after plasma treatment. The surface morphology of the treated fabrics was studied. Fabric tailor ability analysis was used to analyze the surface properties of the treated samples. The yarn pulling-out test shows that the resistance to pulling out yarns from plasma-treated fabrics treated with Ar and N2, the plasma-treated fabric's resistence is increased to $18 \%$ and $300 \%$ respectively, compared with the untreated fabric.

\section{Materials and Methods:}

\section{Experimental Part}

\subsection{Tests: Fabric assurance by simple testing:}

Fabric mechanical properties such as fabric prickliness, itchiness, stiffness, softness, smoothness, roughness, scratchiness, friction and tactile properties may be discussed and warmth or coolness to the touch of fabrics and dampness sensations are explained, by making use of fabric assurance by simple testing system, FAST.

"FAST", consists of a series of instruments and test methods, which are inexpensive, robust and simple to use. It is used to measure properties that are closely intertwined to the ease of garment manufacturing and the durability of the finished fabric. FAST-1 provides a direct measurement of a fabric's thickness over a range of loads with resolution in the micro-meters. FAST2 , is used to measure the fabric's bending length and it's bending rigidity. FAST-3, is used to provide a measurement of fabric extensibility at low loads as well as its shear rigidity. FAST- 4 is a quick test to measure the fabric's dimensional stability, including both the relaxation shrinkage and the Hygral expansion, i.e., FAST, is a system of objective measurements for assessing the appearance, handle, and performance properties of fabrics, using an integrated set of instruments and test methods [2-8]. The relationship between FAST outputs and overall fabric comfort is clear from the following concepts:

1) Results of FAST 1 - A higher value of fabric thickness -T2, indicates greater compressibility and high thermal comfort level. 
2) Results of FAST 2 - Higher value of fabric bending rigidity, indicate greater stiffness / resistance to bending motions, i.e., good moving comfort.

3) Results of FAST 3 - higher value of fabric extensibility, E100 indicate greater stretch, accepted correlation to moving comfort.

4) Results of FAST 4 - Lower values of shear stiffness, G, indicate less resistance to the shearing motion; corresponds with better drape with excellent correlation to aesthetic comfort.

\subsection{Raw Material}

\subsubsection{Protective clothing}

Past research on the quality of materials used in firefighter protective clothing includes:

- Estimates of Thermal Conductivity for Unconditioned and Conditioned Materials Used in Fire Fighters' Protective Clothing - Estimates of Thermal Protective Properties for Fire Fighters' Protective Clothing Materials Full Ensemble and Bench Scale of Fire Fighter Protective Clothing -

\subsubsection{Complex hazarders (Fire and Fuel) Protective Clothing for Fir-fighters:}

Fire fighters have to be prepared to operate in all parts of the globe from arctic, through temperate, to jungle and desert areas. As such they experience a wide range of climatic possible, fire and heat, engineering rain, snow, fog, wind, lightning , sunlight and dust . They require different uniforms for use in five basic climates: hot-wet, hot-dry, and temperature, cold-wet, and colddry. In hot-wet, hot-dry and temperature environments battledress uniforms are worn that made from $100 \%$ of heavy duty cotton fabric, treated with fire retardant agent, "GF510", according to Egyptian standard .[6]

\section{Results:}

From such study over all fabric comfort, can be divided into two groups:

Positive properties such as formability, extensibility, bending rigidity, and fabric thickness, and negative properties such as hygral expansion, shear rigidity, and fabric weight. Relative characteristics and polygon area for obtained optimum treatment could be calculated by the following equations: 


\section{Where}

$\mathrm{Xi}=$ objective property or typical value of each comfort property (thermal-aesthetic-wear).

$\mathrm{X} \max$ and $\mathrm{X} \min =$ maximum and minimum values of each comfort property. The method chosen here to represent the results mathematically was use. Therefore, these calculations can be used for assessing the suitable fabric treatment for fireman garment against complex hazarders. An inclusive coefficient of comfort performance index (OFCI), can be calculated as follows: $\mathrm{OFCI}=\mathrm{A} / \mathrm{A} \max$

\section{Where}

$\mathrm{A}=$ polygon area of every treatment (wet and / or dry treatment), $\mathrm{A} \max =0.5$ sine $360 / \mathrm{n} * \mathrm{X} 1 \mathrm{X} 2+\mathrm{X} 2 \mathrm{X} 3+\mathrm{X} 3 \mathrm{X} 4 \ldots . .+\mathrm{Xn}-1 \mathrm{X} 1$

\section{Where}

$\mathrm{n}=$ number of selected properties.

For selecting the best protective fabric treatment against complex hazarders (fire and fuel), the suggested method mentioned below could be applied as show in the following, Table [1].

Table [1] shows the typical values of tested fabric properties:

\begin{tabular}{|l|l|l|l|l|l|l|}
\hline $\begin{array}{l}\text { Fabric } / \\
\text { Property }\end{array}$ & $\begin{array}{c}\text { Grey } \\
\text { fabric }\end{array}$ & $\begin{array}{l}\text { G0\% } \\
\text { GF510 }\end{array}$ & $\begin{array}{l}70 \% \\
\text { GF510 }\end{array}$ & $\begin{array}{l}\text { 80\% } \\
\text { GF510 }\end{array}$ & $\begin{array}{l}\text { Plasma } \\
\text { Ar }\end{array}$ & $\begin{array}{l}\text { Ideal } \\
\text { Value }\end{array}$ \\
\hline HE & $1.9(0)$ & $1.1(0)$ & $0.6(0)$ & $0.7(0)$ & $0(1)$ & 0 \\
\hline F & $3.1(1)$ & $0.4(0.1)$ & $1.9(0.7)$ & $1.5(0.5)$ & $11.9(0.6)$ & 3.1 \\
\hline E100 & $1.9(0.8)$ & $0.8(0.3)$ & $0.9(0.4)$ & $0.9(0.4)$ & $2.4(1)$ & 2.4 \\
\hline B & $166.9(1)$ & $59.3(0.4)$ & $146.6(0.9)$ & $127.6(0.4)$ & $70.4(0)$ & 59.3 \\
\hline G & $461(0.4)$ & $273(0.7)$ & $184(1)$ & $351(0.5)$ & $273(0.7)$ & 184 \\
\hline T2 & ..9(0.8) & $0.9(0.9)$ & $1.1(1)$ & $0.9(0.9)$ & $0.9(0.9)$ & 1.1 \\
\hline W & $354(1)$ & $380(0.9)$ & $394(0.9)$ & $384(0.9)$ & $360(0.9)$ & 354 \\
\hline
\end{tabular}

Values between bracts are normalized values. 
Table [1] shows that overall fabric comfort index reaches 3.54 with plasma treatment, and $3.44,1.87,1.82$ with $70 \%, 60 \%, 80$ $\%$ of GF510 retardant agent respectively. Figs. 3- 5, show that results.

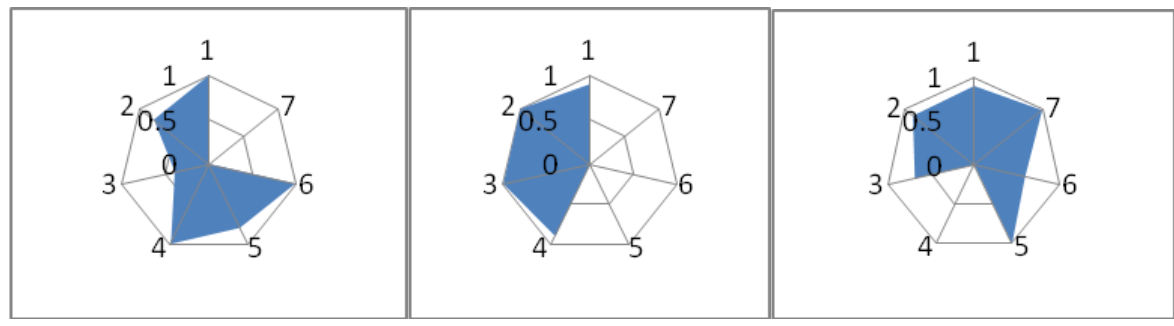

\section{Fig (3)}

Fig (4)

Fig (5)

Fig (3) Overall Fabric Comfort Index (Raw Fabric without treatment)

Fig (4) Overall Fabric Comfort Index (threated fabric with 70\% GF510)

Fig (5) Overall Fabric Comfort Index (plasma treatment with," Ar ").

Results of dry fabric treatment with argon is expected, even argon is not polymerized gas asch as hexamethyldisiloxane (HMDSO), to coat the tested fabric with a layer with high resistance to fire, therefore it is suggested to use polymerized gas instead of no polymerizes gas in preparation of protective fabric against complex hazards fire and fuel. The best fit relationship between fabric tailor ability- extensibility - bend in rigidity-shear rigiditythickness-weight and overall fabric comfort index. Determination coefficient reaches $\left(R^{\wedge} 2\right)$ the highest value $(0.999)$ with fabric formability. It means by knowing the value of fabric formability it is easy to have $99.9 \%$ of the information about overall fabric comfort. Fig.6 shows that relationship.

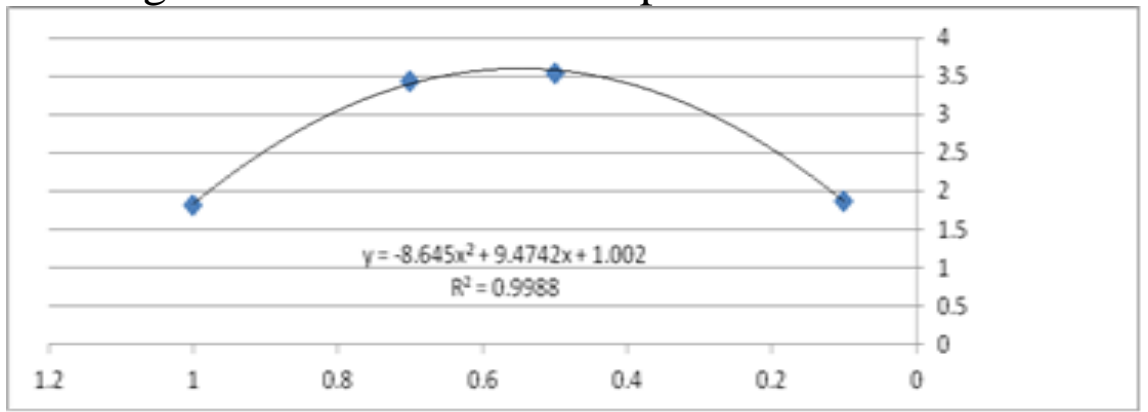


Fig (6) shows the relationship between fabric formability and overall fabric comfort index.

The overall fabric comfort of woven protective fabric against fire and fuel, produced from , $100 \%$ cotton, $13 \mathrm{oz} / \mathrm{y}^{\wedge} 2$, twill 3/1, 0.92 $\mathrm{mm}$, may be influenced by many factors including concentration of fire-retardant agent, raw material properties, and fabric structure. The fabric manufacturer only wishes to determine the optimum percentage of retardant agent at which fabric comfort is at its maximum level. In this case, all other factors should be kept constant and only the percentage of retardant agent will be allowed to change.

This is a single-factor experiment, which the factor being the percentage of "GF510" retardant agent and the response variable being the aesthetic comfort in terms of HE, F, B, and G, wear and / or moving comfort interims of " E100 and W, and thermal comfort interims of T2, of tested fabric. In order to satisfy other quality and processing criteria, the practical range of fire-retardant agent "GF510" was supposed to be between $60 \%$ and 80\% [1]. In this research, manufacturer decided to use three practical levels of concentration agent, namely, 60\%, 70\%, and 80\% [5]. At each level, 3 test replicates of overall fabric comfort were used.

This experiment is summarized in Table [2] Table [2] Summary of the single-factor ANOVA

\begin{tabular}{|c|l|c|c|c|}
\hline $\begin{array}{c}\text { Source of } \\
\text { variation }\end{array}$ & \multicolumn{1}{|c|}{$\begin{array}{c}\text { Sum of } \\
\text { squares }\end{array}$} & $\begin{array}{c}\text { Degree of } \\
\text { freedom }\end{array}$ & $\begin{array}{c}\text { Mean } \\
\text { Square }\end{array}$ & Fo / sig. \\
\hline Regression & $\mathbf{0 . 7 6 3}$ & 3 & $\mathbf{0 . 2 5 4}$ & $\mathbf{6 . 0 3 7 / 0 . 0 8 7}$ \\
\hline & $\mathbf{0 . 1 2 6}$ & 6 & $\mathbf{0 . 0 4 2}$ & \\
\hline Total & $\mathbf{0 . 8 9 0}$ & 8 & & \\
\hline
\end{tabular}

The results of ANOVA Table can be interpreted in the following points:

As shown in Table 2 the value of source mean squares 0.763 is much higher than that of error mean square 0.126 . this resulted in a high $\mathrm{F}$ ratio of 6.037, this means that differences in treatments (differences in concentration of GF 510) lead to significant 
differences in overall fabric comfort. The results obtained show that heavy duty fabric with 70\%, GF510, shows the highest comfort level.

\section{Conclusion}

With low stress applied, as in manipulating / touching fabrics, the Fabric assurance by simple testing (FAST) instruments define the role played by tensile (stretch), shear stiffness (drape), bending rigidity (flexing), compression (thickness, softness), and surface friction and roughness (next to skin) on tactile sensations. From overall fabric comfort index (OFCI), point of view , one may conclude the following main points :

The points to consider in this research are:

1 - Fabric assurance by simple testing "FAST" system can be used to evaluate overall fabric comfort index

2 - The results obtained show that heavy duty cotton fabric with 70\%" GF510", has the highest comfort index.

3 - Dry treatment with non- polymerized gas "Ar" is excellent for treated fire fighter clothes against complex hazards, i.e., fire and fuel.

\section{References:}

[1] Xu W., Liu X. Surface Modification of Polyester Fabric by

Corona Discharge Irradiation. Eur. Polym. J. 2003; 39:199-202. doi: 10.1016/S0014-3057(02)00169-6. [CrossRef] [Google Scholar]

[2] Liu C., Cui N., Brown N.M.D., Meenan B.J. Effects of DBD Plasma Operating Parameters on the Polymer Surface Modification. Surf. Coat. Technol. 2004; 185:311-320. doi: 10.1016/j.surfcoat.2004.01.024. [CrossRef] [Google Scholar]

[3] Walsh J.L., Iza F., Janson N.B., Law V.J., Kong M.G. Three Distinct Modes in a Cold Atmospheric Pressure Plasma Jet. J. Phys. Appl. Phys. 2010; 43:075201. doi: 10.1088/00223727/43/7/075201. [CrossRef] [Google Scholar] 
[4] El-Hadidy, A.M. (2015) Influence of industrial apparel washing on denim fabric properties, SMARTEX, International conference, Sharm, Nov.2015

[5] Egyptian Standard, SE 1124 /72 (2015) .

[6] www.csiro.au/resourrs/siro.FAST, report. htt:) (15.7.2015), www.csiro.au/.../CSIRO\%20Materials\%20Science\%20an

[7] EL-Hadidy, A. (2013): Influence of Plasma Treatment on Cotton Fabric Tailor ability, 3rd International Conference on Recent Advanced in Material Processing Technology (RAMPT, 13), 7 - 9 Jan.2013, India.

[ 8] El-Hadidy, A., EL-Housing, A. and Mohamed, R. EL (2013) Application of Recent Developed Techniques in Textile Finishing, International Journal of Engineering and Science, ISSN: 22784721 